\title{
ДОТРИМАННЯ ПРОЦЕСУАЛЬНОЇ ФОРМИ ЯК КРИТЕРІЙ ДОПУСТИМОСТІ ДОКАЗІВ У КРИМІНАЛЬНОМУ ПРОВАДЖЕННІ
}

\author{
Дрозд В. Г., Абламський С. Є.
}

\section{ВСТУП}

Відповідно до ст. 2 Кримінального процесуального кодексу України (далі - КПК України), одним із завдань кримінального провадження $є$ охорона прав, свобод та законних інтересів його учасників. Однією 3 гарантій додержання прав учасників кримінального провадження $\epsilon$ неухильне дотримання визначеної законом процедури збирання та фіксації доказів, які мають відповідати критеріям належності, допустимості, достовірності та достатності. I як свідчить слідчо-судова практика, саме допустимість доказів $є$ найбільш складним критерієм, порушення якого призводить до визнання зібраних стороною обвинувачення доказів недопустимими i, як наслідок, ухвалення судом виправдувального вироку.

У доктрині кримінального процесу питання щодо допустимості доказів завжди викликали великий науковий інтерес, наочним свідченням чого $\epsilon$ низка різноаспектних досліджень, проведених такими вченими, як: Р.С. Бєлкін, В.В. Вапнярчук, Т.В. Ворфоломєєва, Ю.М. Грошевий, Т.М. Добровольська, О.В. Капліна, Л.М. Лобойко, В.З. Лукашевич, В.Т. Нор, О.С. Осетрова, В.М. Савицький, С.М. Стахівський, О.Ю. Татаров, О.М. Толочко, В.В. Тютюнник, Ф.Н. Фаткуллін, О.Г. Шило, М.Є. Шумило й ін. Науково-теоретичні результати, отримані цими й іншими правниками, нерозривно пов'язані із практичними проблемами реалізації положень кримінального процесуального законодавства в частині порядку збирання доказів. Адже порушення процесуального закону призводить до визнання як окремого доказу, так і всіх інших, отриманих на його основі, недопустимими (доктрина «плодів отруйного дерева» (fruit of the poisonous tree)*.

Реалії правозастосовної практика свідчать про те, що натепер існує багато прикладів неоднозначного тлумачення та застосування положень КПК України щодо визнання доказів недопустимими. Не є винятком із

\footnotetext{
* Доктрина "fruit of the poisonous tree" прийшла sз країн з англо-саксонською системою права та в подальшому знайшла своє відображення в низці рішень Європейського суду з прав людини, зокрема, у справах «Гефген проти Німеччини», «Тейксейра де Кастро проти Португалії», «Хан проти Сполученого Королівства», «Шабельник проти України», «Балицький проти України», «Нечипорук і Йонкало проти України», «Яременко проти України» тощо.
} 
цього й порушення процесуальної форми отримання доказів, що, звісно, призводить до визнання їх недопустимими. 3 огляду на це вельми актуальним $\epsilon$ дослідження проблемних аспектів дотримання процесуальної форми як критерію допустимості доказів. Насамперед пояснюється це тим, що забезпечення допустимості доказів $\epsilon$ передумовою ухвалення законного, обгрунтованого та справедливого судового рішення.

\section{1. Допустимість доказу крізь призму вимог закону}

Згідно із приписами ст. 62 Конституції України та рішення Конституційного Суду України від 20 жовтня 2001 р. № 12-рп/2011, обвинувачення не може грунтуватися на доказах, одержаних незаконним шляхом, тобто з порушенням конституційних прав і свобод людини i громадянина або встановлених законом порядку, засобів, джерел отримання таких доказів. Визнаватися допустимими і використовуватися як докази у кримінальній справі можуть тільки фактичні дані, одержані відповідно до вимог законодавства. Перевірка доказів на їхню допустимість $є$ гарантією забезпечення прав i свобод людини $\mathrm{i}$ громадянина у кримінальному процесі й ухвалення законного i справедливого рішення у справі ${ }^{1}$. Отже, допустимість доказів є гарантією забезпечення прав учасників кримінального провадження та законності процесуальних рішень на стадії як досудового розслідування, так i судового розгляду кримінального провадження.

Кримінальний процесуальний закон не дає вичерпного переліку підстав, за наявності яких докази мають визнаватися недопустимими, натомість надає право суду вирішувати питання їхньої допустимості чи недопустимості в порядку, передбаченому ст. 89 КПК України. Зокрема, питання допустимості доказів вирішує суд під час їх оцінювання в нарадчій кімнаті у процесі ухвалення судового рішення. У разі встановлення очевидної недопустимості доказу під час судового розгляду суд визнає цей доказ недопустимим, призводить до неможливості дослідження такого доказу або припинення його дослідження в судовому засіданні, якщо таке дослідження було розпочате.

Сторони кримінального провадження, потерпілий, представник юридичної особи, щодо якої здійснюється провадження, мають право під час судового розгляду подавати клопотання про визнання доказів недопустимими, а також наводити заперечення проти визнання доказів недопустимимиㄹ․

\footnotetext{
1 Конституція України : Закон України від 28 червня 1996 p. № 254к/96-BP. URL: http://zakon1.rada.gov.ua/laws/show/254к/96-BP ; Рішення Конституційного суду України від 20 жовтня 2001 p. № 12-pп/2011. URL: https://zakon.rada.gov.ua/laws/show/v012p710-11.

2 Кримінальний процесуальний кодекс України від 13 квітня 2012 р. № 4651-VI. URL: http://zakon2.rada.gov.ua/laws/show/4651-17.
} 
Отже, саме суд відіграє вирішальну роль у визначенні допустимості того чи іншого доказу, ухвалює відповідне рішення на підставі оцінки допустимості, достовірності, достатності та належності доказів, які надали йому сторони на підтвердження своїх правових позицій. У цьому ракурсі суд має брати до уваги загальновизнані в доктрині кримінального процесу критеріями допустимості доказів, а саме: 1) дотримання процесуальної форми отриманих доказів; 2) збирання доказів належним суб'єктом кримінального процесу; 3) належне джерело отримання доказів; 4) належний спосіб отримання доказів. Уважаємо, під час вирішення питання допустимості доказу суд повинен ураховувати не тільки дотримання суб'єктами передбаченого законодавством порядку щодо їх збирання та фіксації, а й значення кожного конкретного доказу для встановлення обставин кримінального провадження, а також наслідки, які мають місце в разі допущення доказу, який було отримано не в установленому законом порядку. Зазначене цілком відповідає засаді змагальності сторін та свободи в поданні ними суду своїх доказів і в доведенні перед судом їхньої переконливості (ст. 22 КПК України). Водночас необхідно брати до уваги і той факт, що отримання доказів унаслідок істотного порушення прав та свобод людини є підставою для визнання їх недопустимими (ст. 87 КПК України).

Отже, під час оцінки доказів суд має керуватися загальновизнаними критеріями допустимості доказів, принципом безпосередності дослідження показань, речей і документів, ураховувати преюдиціальне значення інших судових рішень, а також оцінювати всю сукупність зібраних доказів у взаємозв'язку та взаємозалежності. Саме такий підхід дозволить забезпечити виконання завдань кримінального провадження та додержання конституційних прав і законних інтересів усіх його учасників.

Дослідження судової практики визнання доказів недопустимими свідчить про численні порушення порядку проведення процесуальних дій стороною обвинувачення. А згідно 3 наведеними О.С. Осетровою емпіричними даними, більшість із таких порушень стосуються саме недотримання процесуальної форми отримання доказів (86\%). Водночас відсоткові значення інших порушень такі: одержання доказів на підставі недопустимих - 32\%; неналежний суб'єкт доказування - 34\%; неналежне джерело доказів - 41\%; неналежний спосіб одержання доказів - 52\%; поєднання декількох порушень - 57\%. За даними опитування, проведеного дослідницею, 95\% слідчих допускали порушення під час проведення й оформлення результатів процесуальних дій ${ }^{3}$.

\footnotetext{
${ }^{3}$ Осетрова О.С. Визнання доказів недопустимими у кримінальному провадженні : дис..... канд. юрид. наук: 12.00.09. Київ, 2016. С. 79-80.
} 
Відповідно до вимог закону, зміст і форма кримінального провадження мають відповідати його загальним засадам, визначеним у ст. 7 КПК України. Здебільшого в наукових джерелах процесуальна форма визначається як умова та послідовність (порядок) проведення процесуальних дій і ухвалення рішень, а також здійснення провадження загалом ${ }^{4} .3$ урахуванням цього процесуальну форму кримінального провадження доцільно розглядати у двох аспектах, а саме:

- по-перше, у широкому розумінні - як установлені кримінальним процесуальним законодавством порядок і умови здійснення досудового розслідування та судового розгляду взагалі;

- no-друге, у вузькому розумінні - як порядок проведення окремих слідчих (розшукових) дій, негласних слідчих (розшукових) дій та інших процесуальних дій, а також ухвалення процесуальних рішень.

Порушення процесуальної форми, що, безумовно, впливає на допустимість доказів, має місце внаслідок: 1) порушення процедурних вимог закону щодо здійснення процесуальних дій; 2) порушення прав і свобод особи; 3) недотримання загальних правил кримінального провадження ${ }^{5}$.

\section{2. Визнання доказів недопустимими внаслідок порушення процесуальної форми: аналіз судової практики}

Виходячи 3 аналізу судових рішень, які містяться в Єдиному державному реєстрі судових рішень, найбільш поширеними прикладами порушення процесуальної форми, зокрема стосовно недотримання вимог закону щодо здійснення процесуальних дій, є: проведення обшуку без понятих; пред'явлення об'єкта для впізнання без дотримання вимоги закону щодо їх кількості; відсутність встановлених кримінальним процесуальним законодавством необхідних реквізитів процесуальних документів тощо. Звісно, такий стан речей негативно позначається на дотриманні прав, свобод та законних інтересів осіб, які залучаються до сфери кримінального процесу.

Беручи до уваги викладене, більш детально зупинимося на такому критерії допустимості доказів, як дотримання прав і свобод людини, оскільки, на наше переконання, 3 одного боку, він $є$ одним 3 основних і

\footnotetext{
${ }^{4}$ Якуб М.Л. Процессуальная форма в советском уголовном процессе. Москва : Юрид. лит., 1981. С. 9 ; Уголовно-процессуальное право Российской Федерации : учебник / отв. ред. П.А. Лупинская. 2-е изд., перераб. и доп. Москва : Норма, 2009. С. 58.

5 Орлов Ю.К. Проблемы теории доказательств в уголовном процессе. Москва : Юрист, 2009. С. 73 ; Вапнярчук В.В. Правові наслідки порушення процесуальної форми збирання доказів у кримінальному провадженні. Публічне право. 2015. № 3 (19). С. 202.
} 
пріоритетним у системі критеріїв допустимості доказів, а 3 іншого найбільш уразливим із погляду порушень прав учасників.

У положеннях ст. 87 КПК України визначені критерії недопустимості доказів, отриманих внаслідок істотного порушення прав та свобод людини. Зокрема, докази, отримані внаслідок істотного порушення прав та свобод людини, гарантованих Конституцією та законами України, міжнародними договорами, згода на обов'язковість яких надана Верховною Радою України, а також будь-які інші докази, здобуті завдяки інформації, отриманій внаслідок істотного порушення прав та свобод людини, $\epsilon$ недопустимими. До таких порушень КПК відносить: здійснення процесуальних дій, які потребують попереднього дозволу суду, без такого дозволу або 3 порушенням його суттєвих умов; отримання доказів унаслідок катування, жорстокого, нелюдського або такого, що принижує гідність особи, поводження або погрози застосування такого поводження; порушення права особи на захист; отримання показань чи пояснень від особи, яка не була повідомлена про своє право відмовитися від давання показань та не відповідати на запитання, або їх отримання 3 порушенням цього права; порушення права на перехресний допит.

Недопустимими також є докази, що були отримані: 1) з показань свідка, який надалі був визнаний підозрюваним чи обвинуваченим у цьому кримінальному провадженні; 2) після початку кримінального провадження шляхом реалізації органами досудового розслідування чи прокуратури своїх повноважень, не передбачених КПК, для забезпечення досудового розслідування кримінальних правопорушень; 3) під час виконання ухвали про дозвіл на обшук житла чи іншого володіння особи у зв'язку 3 недопущенням адвоката до проведення цієї слідчої (розшукової) дії. Факт недопущення до участі в обшуку адвокат зобов'язаний довести в суді під час судового провадження; 4) під час виконання ухвали про дозвіл на обшук житла чи іншого володіння особи, якщо така ухвала винесена слідчим суддею без проведення повної технічної фіксації засідання ${ }^{6}$.

Крім того, істотним порушенням прав і свобод особи Верховний Суд визнав затримання особи без складення протоколу затримання та без роз'яснення особі іiі прав. Так, після безпосереднього дослідження як доказу протоколу огляду місця події, згідно з яким обвинувачений надав психотропну речовину працівникам поліції, Суд дійшов висновку, що вказаний документ не $є$ допустимим джерелом доказів, адже наведені в ньому фактичні дані було отримано 3 істотним порушенням вимог кримінального процесуального закону. Зокрема, Судом було встановлено,

\footnotetext{
${ }^{6}$ Кримінальний процесуальний кодекс : Закон України від 13 квітня 2012 р. № 4651-VI. URL: http://zakon2.rada.gov.ua/laws/show/4651-17.
} 
що працівники поліції зупинили обвинуваченого 15 травня 2017 p. приблизно о 16:00, а протокол складено лише після приїзду слідчооперативної групи в період 17:00-17:15 слідчим. Як убачається зі змісту протоколу, обвинувачений особисто витягнув із передньої кишені штанів і передав працівникам поліції пакети із психотропною речовиною.

Згідно 3 даними, відображеними на носії інформації, на якому зафіксовано перебіг судового засідання, свідок у своїх показаннях зазначив, що він, прибувши за викликом про затримання особи, стосовно якої є підозра у зберіганні наркотичних засобів, побачив на місці події обвинуваченого 3 кайданками на руках в оточенні інших працівників поліції. Відповідно до ст. 209 КПК України, особа $€$ затриманою 3 моменту, коли вона силою або через підкорення наказу змушена залишитися поряд з уповноваженою особою. Отже, обставини справи свідчать, що підозрюваний фактично був затриманий, однак усупереч вимогам ч. 5 ст. 208 КПК України протокол про його затримання не було складено, процесуальні права не роз'яснено. Окрім того, допущене порушення визнано судом істотним і за відсутності оформленого відповідно до ч. 3 ст. 208 КПК України протоколу обшуку затриманої особи. Це слугувало підставою для поставлення під сумнів законності протоколу огляду місця події, на якому вирішальною мірою грунтується обвинувачення. 3 урахуванням установлених процесуальних порушень, факту недодержання конституційних прав i свобод людини Суд, керуючись ст. 87 КПК України, також визнав недопустимими решту доказів сторони обвинувачення, які $є$ похідними від протоколу огляду місця події.

Наведена позиція Суду узгоджується із практикою Європейського суду 3 прав людини (далі - ССПЛ) (рішення від 30 червня 2008 р. у справі «Гефген проти Німеччини», від 21 квітня 2011 р. у справі «Нечипорук і Йонкало проти України» ${ }^{9}$ ). Зокрема, відповідно до позиції ЄСПЛ, викладеної в зазначених рішеннях, якщо джерело доказів $є$ недопустимим, то всі інші фактичні дані, отримані за його допомогою, будуть такими ж.

Схожа ситуація склалася під час розгляду іншого кримінального провадження, у якому судом визнано недопустимим доказом протоколи огляду місцевості, приміщення, речей та документів i протокол

\footnotetext{
${ }^{7}$ Постанова Колегії суддів Касаційного кримінального суду Верховного Суду від 21 січня 2020 р. (справа № 756/8425/17; провадження № 51-859км19). URL: http://www.reyestr.court.gov.ua/Review/ 87053575.

8 Дело «Гефген против Германии» (“Gafgen v. Germany”) : постановление Европейского суда по правам человека от 30 июня 2008 г. URL: http://www.echr.ru/documents/doc/5592512/5592512.htm.

${ }^{9}$ Справа «Нечипорук і Йонкало проти України» : рішення Свропейського суду з прав людини від 21 липня 2011 p. URL: https://zakon.rada.gov.ua/laws/show/974_683.
} 
освідування особи. Суд дійшов такого висновку з огляду на те, що обставини, викладені у протоколах та відеозаписі цих слідчих (розшукових) дій, не відповідають їхньому змісту, передбаченого законом. Зокрема, слідчі фактично провели не огляд місцевості, приміщення, речей та документів, а відкрите фіксування під час завершальної стадії контролю за вчиненням злочину 3 фактичним затриманням обвинуваченого та вилученням грошей, які були в нього в кишені, де мали керуватися ст. ст. 208, 209, ч. 4 ст. 271 КПК України. Судом визнано безпідставним твердження сторони обвинувачення про добровільну участь обвинуваченого у слідчих діях, проведених негайно після його фактичного затримання, - освідуванні й огляді місцевості, приміщення, речей та документів, оскільки в розумінні ст. 209 КПК України його було затримано, що зобов'язувало слідчого повідомити затриманого про його процесуальні права, передбачені ч. 4 ст. 208 КПК України. Однак такі вимоги процесуального закону не було дотримано, протокол затримання особи та докази роз'яснення йому прав у матеріалах кримінального провадження відсутні. Отже, колегія суддів Верховного Суду визнала як порушення форми кримінального процесу, так і таких загальних засад кримінального провадження, як законність та забезпечення права на захист, що стало підставою для визнання цих доказів та похідних від них недопустимими ${ }^{10}$.

Наведений випадок порушення права на захист, що відповідно до закону становить істотне порушення прав і свобод особи та призводить до визнання доказів недопустимими, непоодинокий. Іншим прикладами порушення права на захист $є$ незалучення захисника відразу після затримання особи та проведення слідчих (розшукових) дій до його призначення. Так, у кримінальному провадженні за ч. 2 ст. 187 Кримінального кодексу (далі - КК) України Судом встановлено, що обвинувачений із 17:40 17 серпня 2017 р. перебував у приміщенні Південно-Західного відділення поліції Хмельницького відділу поліції ГУНП у Хмельницькій області, звідки його було доставлено у приміщення слідчого відділу Хмельницького відділу поліції ГУНП у Хмельницькій області, тобто, з огляду на положення ст. 209 КПК України, фактично був затриманою особою. Верховним Судом визначено порушення права на захист зазначеної особи, оскільки в порушення ч. 4 ст. 213 КПК України Регіональний центр із надання безоплатної вторинної правової допомоги у Хмельницькій області не було негайно повідомлено про затримання особи,

\footnotetext{
${ }^{10}$ Постанова колегії суддів Третьої судової палати Касаційного кримінального суду Верховного Суду від 18 грудня 2019 р. (справа № 588/1199/16-к; провадження № 51-3127км19). URL: http://www.reyestr.court.gov.ua/Review/86505861.
} 
що підтверджується відомостями, зазначеними у протоколі затримання особи, підозрюваної у вчиненні злочину, який було складено о 00:40 18 серпня 2017 p. Також порушенням права на захист визнано проведення таких слідчих дій, як пред'явлення особи для впізнання до складання протоколу про іiї затримання та до призначення їй захисника ${ }^{11}$.

Необхідно звернути увагу на той факт, що забезпечення участі підозрюваного та його захисника за їхнім клопотанням у слідчих (розшукових) діях є правом, а не обов'язком сторони обвинувачення. Так, в одному із кримінальних проваджень встановлено, що підозрюваним та його захисником були подані клопотання про забезпечення їхньої участі у проведенні слідчих (розшукових) дій. Зазначені клопотання слідчим задоволено, про що письмово повідомлено підозрюваного та його захисника. Водночас про проведення слідчого експерименту підозрюваного та його захисника не повідомлено, їхня участь не забезпечена. На думку суддів Верховного Суду, протокол, складений за результатами зазначеної слідчої дії, не $є$ недопустимим доказом, оскільки згідно із ч. 3 ст. 240 КПК України до участі у слідчому експерименті можуть бути залучені підозрюваний, потерпілий, свідок, захисник, представник. Тому, як убачається із приписів указаної статті, залучення осіб як учасників слідчого експерименту, $\epsilon$ правом, а не обов'язком слідчого, а отже, саме останнім ухвалюється рішення із зазначеного питання. Наведене узгоджується із правовою позицією, викладеною в постанові Касаційного кримінального суду Верховного Суду від 10 липня 2018 р. (справа № 387/1088/16-к, провадження № 51-2752км18), згідно з якою проведення таких слідчих (розшукових) дій, як допит свідків, слідчі експерименти, призначення експертизи, не потребує обов' язкової участі підозрюваного, якщо інше не визначено слідчим ${ }^{12}$.

Прикладом визнання недопустимим доказом показань свідка, який надалі був визнаний підозрюваним у цьому кримінальному провадженні, $є$ ситуація, коли на час отримання показань від свідка вже існували дані, що його буде визнано підозрюваним. Натомість, усупереч наявності в такої особи права на мовчання та свободи від самовикриття, слідчий, прокурор вчиняє дії, спрямовані на отримання показань від неї. Саме такі дії, а не власне факт отримання показань від свідка, який надалі був визнаний підозрюваним, мають визнаватися істотним порушенням прав людини і основоположних свобод. Так, Верховним Судом встановлено, що слідчим за участю свідка

\footnotetext{
${ }^{11}$ Постанова колегії суддів Третьої судової палати Касаційного кримінального суду Верховного суду від 15 липня 2019 p. (справа № 686/19218/17; провадження № 51-3118км19). URL: http://reyestr.court.gov.ua/Review/86035312.

12 Постанова колегії суддів Третьої судової палати Касаційного кримінального суду Верховного Суду від 11 березня 2020 p. (справа № 149/745/14; провадження № 51-4269км19). URL: http://www.reyestr.court.gov.ua/Review/88265263.
} 
оглянуто дані відеозапису з камер відеоспостереження, на якому зафіксовано факт учинення крадіжки металевої решітки, під час якого свідок упізнав себе як особу, яка вчиняє крадіжку. Після проведення зазначеного огляду предметів останньому було повідомлено про підозру у вчиненні злочину, передбаченого ч. 2 ст. 185 КК України, а прокурором затверджено обвинувальний акт і в цей же день скеровано до суду. Ураховуючи ці обставини, суд апеляційної інстанції дійшов обгрунтованого висновку, що дані протоколу огляду речових доказів у частині впізнання свідком себе як особи, що вчинила крадіжку, який у подальшому був визнаний підозрюваним і обвинуваченим, варто визнати недопустимим відповідно до ч. 3 ст. 87 КПК України. Показання, отримані від особи, яка фактично підозрюється у вчиненні злочину та допитувалася щодо фактів і обставин його вчинення як свідок із попередженням про кримінальну відповідальність за завідомо неправдиві показання чи за відмову давання показань, не мають доказової сили. Це випливає із суттєвих відмінностей процесуального положення i порядку допиту свідка та підозрюваного (обвинуваченого). Свідок зобов'язаний давати показання під загрозою кримінальної відповідальності, а підозрюваний має право відмовитися від дачі показань. За загальним юридичним правилом ніхто не може бути свідком у своїй справі, тому свідком може бути особа, яка не є підозрюваним або обвинуваченим. У тих випадках, коли особа допитувалася як свідок, а в подальшому набула статусу підозрюваного й обвинуваченого, попередні ії показання втрачають властивості доказів, оскільки були отримані з неналежного процесуального джерела. Ураховуючи зазначене, колегія суддів Касаційного кримінального суду Верховного Суду погодилася з рішенням суду апеляційної інстанції щодо недопустимості протоколу огляду речових доказів у частині впізнання свідком себе як особи, що вчинила крадіжку ${ }^{13}$.

Прикладом недотримання загальних правил кримінального провадження, що призводить до визнання доказів недопустимими, також $\epsilon$ проведення слідчих (розшукових) дій до внесення відомостей до Єдиного реєстру досудових розслідувань (далі - ЄРДР) або після закінчення досудового розслідування. Так, Суд уважає недотримання процесуального закону під час пред'явлення потерпілим осіб для впізнання за фотознімками до внесення відомостей до $Є Р Д \mathrm{P}^{14}$, що цілком відповідає вимогам ч. 3 ст. 214 КПК України. Адже виключно огляд місця події може бути проведений до внесення відомостей до ЄРДР.

\footnotetext{
${ }^{13}$ Постанова колегії суддів Першої судової палати Касаційного кримінального суду Верховного Суду від 2 травня 2018 p. (справа № 464/5860/16-к; провадження № 51-5134ск18). URL: http://reyestr.court.gov.ua/Review/73770660.

${ }^{14}$ Постанова колегії суддів Першої судової палати Касаційного кримінального суду Верховного Суду від 11 квітня 2019 р. (справа № 642/5974/13-к; провадження № 51-7304км18). URL: http://www.reyestr.court.gov.ua/Review/81264179.
} 
Окремо варто звернути увагу на рішення Верховного Суду щодо визнання недопустимим доказом відеозапису з камери відеоспостереження, який був добровільно виданий потерпілим до внесення відомостей до ЄРДР. Своє рішення Суд мотивував тим, що диск відеозапису з камер спостереження магазину, який покладено судом першої інстанції в основу обвинувального вироку, був отриманий від потерпілого не уповноваженою на те посадовою особою органу досудового розслідування без дотриманням вимог кримінального процесуального закону, а тому доводи сторони обвинувачення щодо їхньої допустимості є такими, що не грунтуються на вимогах закону. Так, за матеріалами кримінального провадження відеодиск iз записом із камер відеоспостереження був добровільно виданий потерпілим оперуповноваженому 1 листопада 2017 р., а відомості про вчинення крадіжки були внесені до СРДР 2 листопада 2017 р. Суд касаційної інстанції вважає, що в даному разі отримання оперативним працівником відеодиска суперечить вимогам ч. ч. 1, 2 ст. 41 КПК, оскільки оперативний працівник у порушення вимог КПК без доручення слідчого не уповноважений здійснювати процесуальні дії із власної ініціативи, тобто в непередбаченому кримінальним процесуальним законодавством порядку. Крім того, як убачається із протоколу огляду місця події, у процесі огляду було встановлено, що у приміщенні магазину ведеться відеоспостереження, однак слідчим будь-яких записів не вилучалося, вони йому йому не надавалися. Доводи прокурора про те, що за ст. 93 КПК сторони наділені правом на збирання та надання доказів, отже, потерпілий має право добровільно видати диск 3 відеозаписом із камер відеоспостереження магазину, що відповідно не може бути наслідком визнання такого доказу недопустимим, колегія суддів уважає такими, що не грунтуються на вимогах закону. Адже, правом витребувати від будь-якої особи необхідні речі, документи, відомості, тощо наділений слідчий, а не оперативний працівник, i лише в рамках кримінального провадження. У даному кримінальному провадженні судом установлено, що процесуальні дії оперативний працівник поліції проводив до внесення відомостей в ЄРДР. 3 огляду на це Суд зазначив, що здійснення процесуальної дії зі збирання доказів і отримання такого доказу, як відеодиск із записом із камер відеоспостереження магазину, оперативним працівником відбулося поза межами кримінального провадження, тобто до внесення відомостей у ЄРДР, а також до проведення огляду місця події, який здійснювався слідчим, що підтверджується відповідним протоколом ${ }^{15}$.

\footnotetext{
15 Постанова колегії суддів Третьої судової палати Касаційного кримінального суду Верховного Суду від 7 серпня 2019 p. (справа № 607/14707/17; провадження № 51-2604км19). URL: http://www.reyestr.court.gov.ua/ Review/83589933.
} 
У практичній площині також непоодинокі випадки порушення процедурних вимог закону щодо здійснення процесуальних дій. Зокрема, Суд визнав недопустимим доказом протокол допиту потерпілого через те, що в ньому не зазначено відомостей про особу, яка провела допит, немає підпису цієї особи, а також у протоколі зазначено причину виклику свідка на допит, яка не має стосунку до справи. На підставі зазначеного протоколу допиту проведено інші процесуальні дії, які були визнані Судом недопустимими доказами за принципом «плодів отруйного дерева», зокрема ухвала слідчого судді про тимчасовий доступ до речей $\mathrm{i}$ документів ${ }^{16}$.

В іншому кримінальному провадженні недопустимим доказом визнано протокол освідування особи з таким мотивуванням: «Відповідно до ст. 241 КПК України, освідування є слідчою (розшуковою) дією, яка здійснюється на підставі постанови прокурора щодо підозрюваного, свідка чи потерпілого. Перед початком освідування особі, яка підлягає освідуванню, пред'являється відповідна постанова прокурора. Водночас у протоколі освідування особи не було зазначено його процесуальний статус, не роз'яснено особі права під час проведення даної слідчої (розшукової) дії. До того ж, як встановлено судом, протокол затримання особи не складався. Іншого належного підтвердження роз'яснення особі іï прав у кримінальному провадженні під час проведення таких слідчих (розшукових) дій, як освідування й огляд (місцевості, речей та документів), про що складено протоколи, суду не надано. Незважаючи на вказівку у протоколі освідування особи на те, що воно проводиться на підставі постанови прокурора, відомості про пред'явлення цієї постанови особі до проведення освідування в матеріалах кримінального провадження відсутні». Отже, Верховним Судом констатовано, що внаслідок викладених порушень кримінального процесуального закону було порушено форму кримінального процесу, що $\epsilon$ основною гарантією забезпечення засади законності, адже затриманий був позбавлений права на захист, права висловлювати свої заперечення чи зауваження стосовно проведених щодо нього процесуальних дій ${ }^{17}$.

В іншому рішенні встановлено порушення визначеного процесуального порядку проведення пред'явлення особи для впізнання за участю свідка слідчої, унаслідок чого протокол цієї слідчої (розшукової) дії визнано

\footnotetext{
${ }^{16}$ Постанова колегії суддів Касаційного кримінального суду Верховного Суду від 8 жовтня 2019 p. (справа № 639/8329/14-к; провадження № 51-8259км18). URL: http://www.reyestr.court.gov.ua/Review/ 85238666 .

${ }^{17}$ Постанова колегії суддів Третьої судової палати Касаційного кримінального суду Верховного Суду від 18 грудня 2019 р. (справа № 588/1199/16-к; провадження № 51-3127км19). URL: http://www.reyestr.court.gov.ua/Review/86505861.
} 
недопустимим доказом. Зокрема, слідчим не було дотримано вимог ч. 3 ст. 228 КПК України, де встановлено, що особі, яка впізнає, пропонується вказати на особу, яку вона має впізнати, і пояснити, за якими ознаками вона ії впізнала. Натомість, перед пред'явленням особи для впізнання свідок не описав зовнішнього вигляду особи, яку має впізнавати, зазначив, що зможе впізнати таку особу за віком, зростом, тілобудовою та рисами обличчя, водночас не конкретизував їх. Проте впізнала невідому особу за віком, рисами обличчя, тілобудовою, а також за одягом, у якому цей же чоловік був одягнений під час учинення злочину, водночас не заявляла до проведення впізнання про одяг як прикмету.

Крім того, не було взято до уваги положення ч. 2 ст. 228 КПК, відповідно до якої особа, яка підлягає впізнанню, пред'являється особі, яка впізнає, разом з іншими особами тієі ж статі, яких має бути не менше трьох і які не мають різких відмінностей у віці, зовнішності й одязі. Але всупереч зазначеному положенню особа, що пред'являлася для впізнання, була одягнена в сині джинси та сіру куртку, а троє інших осіб, які пред'являлися 3 нею до впізнання, були одягнені в чорні куртки і чорні штани ${ }^{18}$.

В іншому кримінальному провадженні протокол пред'явлення особи для впізнання визнано судом недопустимим доказом на підставі того, що така слідча (розшукова) дія було проведена за відсутності понятих та 3 порушенням порядку пред'явлення особи для впізнання за фотознімками. Так, відповідно до вимог ст. 228 КПК України, перед тим, як пред’явити особу для впізнання, слідчий, прокурор попередньо з'ясовує, чи може особа, яка впізнає, впізнати цю особу, опитує ії про зовнішній вигляд і прикмети цієї особи, а також про обставини, за яких вона бачила цю особу, про що складає протокол. Якщо особа заявляє, що вона не може назвати прикмети, за якими впізнає особу, але може впізнавати іiі за сукупністю ознак, у протоколі зазначається, за сукупністю яких саме ознак вона може впізнати особу. Забороняється попередньо показувати особі, яка впізнає, особу, що повинна бути пред'явлена для впізнання, та надавати інші відомості про прикмети цієї особи. Відповідно до ч. ч. 1, 2, 6, 7 ст. 228 КПК України, встановлений порядок впізнання особи за фотознімками. Однак Судом були встановлені порушення вказаних норм. 3 показань потерпілої та свідка вбачається, що обвинуваченого перед впізнанням, яке було здійснено у відділенні міліції, пред'явили потерпілій на вулиці. Водночас інші особи для впізнання їй не пред'являлися в цей час. Також потерпіла вказала, що впізнання на досудовому розслідуванні за

\footnotetext{
${ }^{18}$ Постанова колегії суддів Третьої судової палати Касаційного кримінального суду Верховного Суду від 7 серпня 2019 p. (справа № 607/14707/17; провадження № 51-2604км19). URL: http://www.reyestr.court.gov.ua/Review/83589933.
} 
фотознімками відбулося за їі участі вже після того, як працівник міліції попередньо продемонстрував їй на вулиці затриманого як схожого за іiі описом чоловіка, якого вона пізніше впізнавала у процесі слідчої дії. Зазначала, що особи, які пред'являлися їй для впізнання, мали інші ознаки зовнішності за тілобудовою, за віком, зростом, були старші за затриману особу. Сам же затриманий заперечував вчинення грабежу стосовно потерпілої. Також він зазначав, що його повторно представили для впізнання потерпілій серед осіб, які за зовнішністю не були подібні до нього, мали суттєві відмінності.

У сукупності доказів, на яких базувалось обвинувачення, протокол пред'явлення особи для впізнання відігравав вирішальну роль, він був елементом, що об’єднував, закріплював, адже протокол огляду місця події, протокол слідчого експерименту за участю потерпілої $є$ непрямими доказами, вони мали значення для доведення вини підозрюваного лише в сукупності із протоколом пред'явлення особи для впізнання. Отже, суди першої, апеляційної та касаційної інстанцій уважають, що зазначенні вище докази не можуть бути достатньою підставою для висновку суду про винуватість обвинуваченого у вчиненні ним грабежу щодо потерпілої ${ }^{19}$.

\section{ВИСНОВКИ}

Беручи до уваги проведене дослідження, можна констатувати, що однією з невід'ємних складових частин гарантій забезпечення досягнення завдань кримінального провадження $є$ дотримання процесуальної форми, зокрема й під час проведення процесуальних дій. 3 одного боку, це забезпечить неухильне дотримання прав, свобод та законних інтересів особи, а з іншого - надасть можливість притягнути особу, яка вчинила кримінальне правопорушення, до відповідальності, відповідно до іiї вини.

На нашу думку, урахування наведених прикладів порушення кримінальної процесуальної форми під час досудового розслідування в подальшому сприятиме додержанню стороною обвинувачення прав i свобод учасників кримінального провадження. Окрім того, уникнення таких порушень закону підвищить якість роботи правоохоронних органів, забезпечить додержання верховенства права й законності з огляду на преюдиціальне значення рішень інших судів у питаннях допустимості доказів.

\footnotetext{
19 Постанова колегії суддів Третьої судової палати Касаційного кримінального суду Верховного Суду від 18 грудня 2019 p. (справа № 761/2021/16-к; провадження № 51-3904км19). URL: http://www.reyestr.court.gov.ua/Review/86505832.
} 


\section{АНОТАЦІЯ}

У статті досліджено основні положення кримінального процесуального законодавства щодо визначення допустимості доказів. Визначено, що вирішальну роль у питанні допустимості того чи іншого доказу відіграє суддя, який повинен керуватися загальновизнаними критеріями допустимості доказів, принципом безпосередності дослідження показань, речей і документів, ураховувати преюдиціальне значення інших судових рішень, оцінювати всю сукупність зібраних доказів у взаємозв'язку. 3'ясовано, що саме такий підхід дозволить забезпечити виконання завдань кримінального провадження та забезпечить додержання конституційних прав усіх його учасників.

Під час дослідження загальновизнаних критеріїв допустимості доказів визначено, що найбільш поширені порушення стороною обвинувачення процесуальної форми кримінального провадження, надано іiі визначення. 3'ясовано, що порушення процесуальної форми впливає на допустимість доказів та має місце внаслідок: 1) порушення процедурних вимог закону щодо здійснення процесуальних дій; 2) порушення прав і свобод особи; 3) недотримання загальних правил кримінального провадження. На підставі дослідження судової практики наведено приклади визначених порушень, що має велике значення в питанні допустимості доказів під час досудового розслідування та судового провадження.

\section{ЛІТЕРАТУРА}

1. Конституція України : Закон України від 28 червня 1996 р. № 254к/96BP. URL: http://zakon1.rada.gov.ua/laws/show/254к/96-BP.

2. Рішення Конституційного суду України від 20 жовтня 2001 р. № 12-pп/2011. URL: https://zakon.rada.gov.ua/laws/show/v012p710-11.

3. Кримінальний процесуальний кодекс України : Закон від 13 квітня 2012 p. № 4651-VI. URL: http://zakon2.rada.gov.ua/laws/show/4651-17.

4. Осетрова О.С. Визнання доказів недопустимими у кримінальному провадженні : дис. ... канд. юрид. наук: 12.00.09. Київ, 2016. С. 79-80.

5. Якуб М.Л. Процессуальная форма в советском уголовном процессе. Москва : Юрид. лит., 1981. С. 9 ; Уголовно-процессуальное право Российской Федерации : учебник / отв. ред. П.А. Лупинская. 2-е изд., перераб. и доп. Москва : Норма, 2009. С. 58.

6. Орлов Ю.К. Проблемы теории доказательств в уголовном процессе. Москва : Юрист, 2009. С. 73 ; Вапнярчук В.В. Правові наслідки порушення процесуальної форми збирання доказів у кримінальному провадженні. Публічне право. 2015. № 3 (19). С. 202. 
7. Постанова Колегії суддів Касаційного кримінального суду Верховного Суду від 21 січня 2020 р. (справа № 756/8425/17; провадження № 51-859км19). URL: http://www.reyestr.court.gov.ua/Review/87053575.

8. Дело «Гефген против Германии» ("Gafgen v. Germany") : постановление Европейского суда по правам человека от 30.06.2008 г. URL: http://www.echr.ru/documents/doc/5592512/5592512.htm.

9. Справа «Нечипорук і Йонкало проти України» : рішення Європейського суду 3 прав людини від 21 липня 2011 p. URL: https://zakon.rada.gov.ua/ laws/show/974_683.

10. Постанова колегії суддів Третьої судової палати Касаційного кримінального суду Верховного Суду від 18 грудня 2019 р. (справа № 588/1199/16-к; провадження № 51-3127км19). URL: http://www.reyestr.court.gov.ua/Review/86505861.

11. Постанова колегії суддів Третьої судової палати Касаційного кримінального суду Верховного Суду від 15 липня 2019 р. (справа № 686/19218/17; провадження № 51-3118км19). URL: http://reyestr.court.gov.ua/Review/86035312.

12. Постанова колегії суддів Третьої судової палати Касаційного кримінального суду Верховного Суду від 11 березня 2020 р. (справа № 149/745/14; провадження № 51-4269км19). URL: http://www.reyestr.court.gov.ua/Review/88265263.

13. Постанова колегії суддів Першої судової палати Касаційного кримінального суду Верховного Суду від 2 травня 2018 р. (справа № 464/5860/16-к; провадження № 51-5134ск18). URL: http://reyestr.court.gov.ua/Review/73770660.

14. Постанова колегії суддів Першої судової палати Касаційного кримінального суду Верховного Суду від 11 квітня 2019 р. (справа № 642/5974/13-к; провадження № 51-7304км18). URL: http://www.reyestr.court.gov.ua/Review/81264179.

15. Постанова колегії суддів Третьої судової палати Касаційного кримінального суду Верховного Суду від 7 серпня 2019 р. (справа № 607/14707/17; провадження № 51-2604км19). URL: http://www.reyestr.court.gov.ua/Review/83589933.

16. Постанова Касаційного кримінального суду Верховного Суду України у справі № 639/8329/14-к від 8 жовтня 2019 р. Сдиний державний реєстр судових рішень : сайт. URL: http://www.reyestr.court.gov.ua/ Review/85238666.

17. Постанова Касаційного кримінального суду Верховного Суду України у справі № 588/1199/16-к від 18 грудня 2019 р. Сдиний державний 
реєстр судових рішень : сайт. URL: http://www.reyestr.court.gov.ua/Review/ 86505861.

18. Постанова Касаційного кримінального суду Верховного суду України у справі № 607/14707/17 від 7 серпня 2019 р. Сдиний державний реєстр судових рішень : сайт. URL: http://www.reyestr.court.gov.ua/Review/ 83589933.

19. Постанова Касаційного кримінального суду Верховного Суду України у справі № 761/2021/16-к від 18 грудня 2019 р. Соиний державний реєстр судових рімень : сайт. URL: http://www.reyestr.court.gov.ua/Review/ 86505832.

\section{Information about authors:} Drozd V. G.,

Doctor of Law Sciences, Associate Professor, Senior Scientific Associate, Head of the $3^{\mathrm{d}}$ Department of Research Laboratory of Problems of Legal and Organizational Support of the Ministry Activities The State Research Institute of the Ministry of Internal Affairs of Ukraine 4a, Y. Gutsalo Lane, Kyiv, 01011, Ukraine ORCID ID:0000-0002-7687-7138

Ablamskyi S. Ye.,

$\mathrm{Ph}$. D. of Law Sciences, Associate Professor, Associate Professor at the Department of Criminal Procedure and Organization of Pre-Trial Investigation of the Faculty № 1 Kharkiv National University of Internal Affairs 27, L. Landau avenue, Kharkiv, 61080, Ukraine ORCID ID: https://orcid.org/0000-0003-4716-3985 